ABDI: Jurnal Pengabdian dan Pemberdayaan Masyarakat

ISSN: 2656-369X (Print), 2684-8570 (Online)

Volume 1 No. 1, Juni 2019

http://abdi.ppj.unp.ac.id/index.php/abdi

Email: abdi@ppj.unp.ac.id

DOI: https://doi.org/10.24036/abdi/voll-issl/4

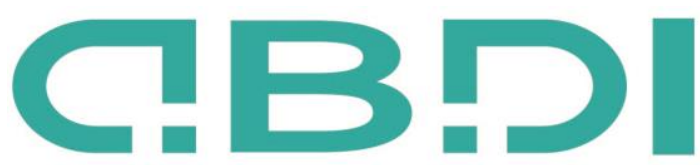

ABDI: JURNAL PENGABDIAN DAN PEMBERDAYAAN MASYARAKAT

\title{
Sinergisitas Pendidikan Karakter dan Sekolah Adiwiyata
}

\author{
Selinaswati Selinaswati \\ Jurusan Sosiologi Universitas Negeri Padang \\ Email: $\underline{\text { selinaswati@fis.unp.ac.id }}$
}

\begin{abstract}
Abstrak
Program Adiwiyata memfokuskan kegiatan pada terciptanya lingkungan sehat dan bersih di lingkungan sekolah, mendidik siswa memiliki kepedulian dan berwawasan lingkungan. Ini berpengaruh pada kelancaran proses belajar mengajar yang baik juga kepada masyarakat di sekitar Lingkungan sekolah. Program yang dicanangkan tahun 2006 ini sudah diterapkan di berbagai sekolah baik tingkat SD, SMP atau SMA.Hanya saja masih ada sejumlah sekolah yang tampak gersang dan jauh dari suasana asri yang mendukung para siswanya belajar dengan nyaman dan memiliki tingkat sadar lingkungan yang tinggi. Salah satunya yaitu SMP 6 Nagari Sungai Nyalo Kecamatan XI Koto, Kabupaten Pesisir Selatan. Sekolah sebagai wadah, lembaga dan institusi yang bertanggung jawab pada perkembangan pengetahuan peserta didiknya. Sekolah juga merupakan wadah menciptakan karakter baik anak. Sehubungan dengan hal tersebut, maka diperlukan pendidikan karakter bagi siswa agar tercipta lingkungan sekolah yang sehat dan bersih. Khalayak sasaran dalam pengabdian ini segenap jajaran sekolah SMP 6. Mereka sebagai khalayak sasaran dipandang cukup strategis karena sekolah sebagai wadah menciptakan karakter baik, sadar lingkungan dan hidup bersih yang bisa diterapkan di rumah masing- masing. Diharapkan juga sekolah berwawasan lingkungan dan menerapkan model pendidikan yang dekat ke alam karena lingkungan mereka bisa dijadikan sebagai sarana belajar pada sejumlah mata pelajaran seperti biologi, pendidikan ekonomi. Pelatihan cara menerapkan lingkungan sehat di sekolah dilakukan dengan dua cara: 1) Pemberian pengetahuan melalui penyampaian materi tentang lingkungan hidup sehat dan bersih 2) praktek gerakan lingkungan sehat, bersih dan asri melalui penanaman pepohonan, pengadaan tong sampah agar setiap kelas memilikinya dan anak- anak terbiasa membuang sampah di tempat sampah. Dari dua cara tersebut, diharapkan siswa memiliki sikap sadar lingkungan dan terbentuknya sekolah adiwiyata di SMP 6.
\end{abstract}

Keyword: sekolah adiwiyata, pendidikan karakter, lingkungan

\section{Abstract}

The Adiwiyata program focuses on creating a healthy and clean area in the school environment by encouraging students to take care and respect their environment. The program launched in 2006 and it has been implemented in various schools including in primary, secondary and high schools. However, there are still a less number of schools thatapplied this program. One of them is the SMP Negeri 6 Nagari Sungai Nyalo XI Koto Secondary School, South Coast District. Schools play an important role in creating a good character for children. In this context, it is necessary for students to acquire an education of character in order to create a healthy and clean school environment. The target of the program is all members of SMP 6s. They are considered as strategic audiences because the school is still less information about the program and far away from the issues of good green school and friendly environment. It is also hoped that schools will be environmentally sound and will apply educational models close to nature, as their environment can be used as a learning tool for a number of topics such as biology and economic education. The implementation of the program run in two ways: 1) Provide knowledge through the provision of material on a clean and 2) Practicing a healthy environment by putting garbage can and good sanitation surrounding schools; so that every students aware of the celan and sanitation such as they throw garbage in the trash. From these two methods, students should adopt an environmentally friendly attitude and create Adiwiyata schools in the SMP 6.

Keyword: Adiwiyata program, Caharacter bulding, Schools environment

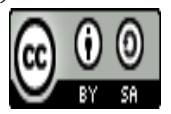

Received: 19 Maret 2019 


\section{Pendahuluan}

Sekolah Adiwiyata, merupakan program Kementrian Lingkungan Hidup dan Kehutanan (KLHKdulu disebut Kementrian Negara Lingkungan hidup KNLH) bekerjasama dengan dengan Kementrian Pendidikan dan Kebudayaan. Konsepnya adalah sekolah yang memiliki wawasan lingkungan dan berbudaya lingkungan; dimana kualitas sekolah menjadi semakin baik karena memiliki lingkungan yang hijau, bersih, sehat dan segar; dan ini mendukung siswa untuk belajar dengan aman, nyaman serta dekat dengan alam dalam melakukan proses belajar mengajar. Program ini secara resmi dibentuk 6 Februari 2006 dengan tujuan para siswa di sekolah memiliki kepedulian dan berpartisipasi aktif dalam pelestarian lingkungan dan pembangunan yang berkelanjutan untuk kepentingan generasi berikutnya.

Dengan demikian, Sekolah Adiwiyata juga memberi kesempatan kepada para siswanya untuk belajar melalui lingkungan sekitarnya dengan tumbuh-tumbuhan yang ada di halaman sekolah. Misalnya dalam mata pelajaran Biologi; mereka belajar tentang tumbuh-tumbuhan bisa praktek langsung dengan tumbuhtumbuhan yang ada di skeitar pekarangan sekolah. Seperti diketahui, salah satu syarat sekolah Adiwiyata, mesti menanam tumbuhan di sekitar sekolah dan mengidentifikasi tumbuhan tersebut dengan menulis apa nama tumbuhan dengan tiga bahasa: bahasa latin, Inggris dan bahasa lokal tentang nama tumbuhan tersebut. Dari segi pendidikan ekonomi, siswa bisa berwirausaha dengan mengelola sampah dan program bank sampah yang difasilitasi dengan baik di sekolah. Dari segi kesehatan dan prilaku hidup bersih, maka siswa sekolah terbiasa mengkonsumsi makanan sehat bebas pengawet dan pewarna, karena salah satu syarat sekolah dengan program adiwiyata adalah sekolah mestu memiliki kantin sehat yang mudah dijangkau dna dikonsumsi makanannya oleh para siswa.

Mengingat akan arti penting program Adiwiyata, maka sekolah sebagai lembaga yang mendidik siswa untuk mendapatkan pengetahuan dan praktek hidup baik dapat pula belajar kebiasaan pola hidup bersih dan sehat serta bisa belajar di lingkungan sekolah yang berwawasan lingkungan. Sejak dicanangkannya program hingga saat ini, sudah cukup banyak sekolah yang menerapkan sekolah Adiwiyata. Tapi kebanyakan sekolah tersebut berada di kawasan perkotaan dan mudah dijangkau oleh transportasi publik. Sedangkan sekolah yang berada di wilayah terpencil dan susah dijangkau masih berkutat dengan persoalan fasilitas mendasar untuk aktifitas proses belajar mengajar seperti buku-buku, mobiler dan sarana prasarana fisik lainnya.

Data tahun 2016 pada Dinas Lingkungan Hidup (DLH) Provinsi Sumatera Barat, dari 19 Kabupaten dan Kota di Sumatera Barat, di Kabupaten Pesisir Selatan hanya 5 sekolah yang menerapkan program Adiwiyata, yakni 3 SD pelaksana program Adiwiyata tingkat provinsi, dan masing-masing satu SD (tingkat Nasional) dan SMP (tingkat Provinsi). Oleh karena tu pelaksanaan sekolah Adiwiyata di daerah yang cendrung terisolir seperti lokasi SMP 6 Sungai Nyalo Mudiak Aie Kecamatan Koto XI Tarusan Kabupaten Pesisir Selatan dianggap satu hal yang cukup menantang dan penting untuk dilakukan mengingat sekolah ini berada dalam kawasan terpadu wisata Mandeh yang sedang digiatkan pelaksanaannya sejak tahun 2015. Dikatakan cukup menantang karena lokasi ini sudah ditetapkan secara resmi dan nasional oleh Kemetrian Pariwisata dan Kementrian Bappenas pada 16 Mei 2015 sebagai kawasan terpadu wisata. Jadi setidaknya partisipasi warga sekitar, termasuk lembaga pendidikan yang ada di sekitar kawasan turut diperhitungkan demi memperindah dan mempercantik kawasan wisata sehingga siap menerima para wisatawan.

Sejumlah kawasan terpadu dimaksud meliputi beberapa nagari yang secara nasional sudah diakui untuk pengembangan wisatanya yakni Nagari Ampang Pulai, Carocok Anau, Sungai Nyalo Mudiak Aie, Mandeh dan Sungai Pinang. Jadi, tampak di sini bahwa Nagari Sungai Nyalo yang terletak di tengah-tengah kawasan wisata terpadu tersebut sebagai bagian wilayah yang dipersiapkan sebagai nagari wisata yang dalam pengembangannya diarahkan pada wisata budaya, kuliner, dan agrowisata untuk jangka waktu beberapa tahun ke depan (Fatimah, 2017). Termasuk juga yang akan dikembangkan lebih jauh adalah jenis wisata bahari dan wisata lingkungan (ecoturism). Dalam rangka kesiapan inilah maka SMP Negeri 6 Sungai Nyalo diharapkan berpartisipasi aktif dalam menggiatkan dinamika pariwisata diwilayahnya dengan memperindah penampilan lembaga pendidikan tersebut.

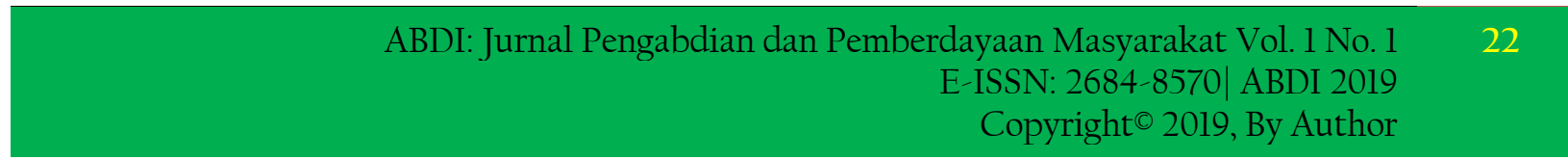


Sejalan dengan program nasional tersebut, maka tim pengabdian masyarakat UNP telah menetapkan salah satu bentuk pengabdian dengan membina dan mengupayakan sekolah SMP Negeri 6 sebagai yang akan diprogramkan menuju sekolah Adiwiyata. Kegiatan ini lebih kongkritnya dalam bentuk pelaksanaan pendidikan karakter bagi guru dan tenaga kependidikan serta para siswa. Pendidikan karakter, seperti didefenisikan oleh Thomas Lickona (1991) adalah usaha yang sengaja dilakukan untuk membantu seseorang agar memiliki pengetahuan, memperoleh pemahaman sehingga ia dapat mengetahui, memiliki, memperhatikan dan melaksanakan nilai-nilai inti, sesuatu nilai baik yang bersifat universal. Jadi melalui pendidikan karakter diharapkan siswa memiliki sikap sadar lingkungan dan memiliki wawasan lingkungan yang baik yang akan menunjang program sekolah Adiwiyata di skeolah mereka.

\section{Metode Pelaksanaan}

SMP 6 Sungai Nyalo ini berada di lokasi yang boleh dikata cukup terisolir, belum bisa diakses internet dan hampir sebagian siswa dan guru menggunakan boat untuk bisa smapai ke sekolah. Kondisi sekolah yang berada pada kawasan yang beriklim tropis dan terkadang 'ekstrim' karena kondisi lingkungan geografis dan alam yang berbukit dan pantai. Utamanya bila terjadi pasang dan dermaga tempat perahu dayung mereka menepi rusak, maka harus menempuh jalan darat melalui perbukitan dan jalan berbatu yang cukup berbahaya.

Dengan kondisi yang serba terbatas ini dapat dimaklumi bila permasalahan mereka terkait dengan menuju skeolah adiwiyata diantaranya; 1) pihak sekolah (siswa dan guru) belum memahami secara komprehensif tentang pentingnya lingkungan sekolah yang bersih, sehat dan asri. 2) Sekolah dan jajarannya masih belum menguasai keterampilan dalam menyiapkan strategi menjadi sekolah adiwiyat dan 3) Sekolah dan jajarannya belum memahami arti penting perlunya pendidikan karakter di sekolah terkait dengan perwujudan lingkungan sehat, bersih dan asri, dimana dalam jangka panjang memiliki pengaruh untuk perubahan masyarakat.

\section{Hasil dan Pembahasan}

Telah dilakukan beberapa kegiatan dalam bentuk tahapan,mulai dari tahap perencanaan, sosialisasi penyuluhan, simulasi, pengenalan lingkungan sehat dan parktek penanaman tumbuhan hijau. Berikut uraiannya satu persatu:

\section{Tahap I}

Pada tahap ini dilakukan semacam perencanaan. Tim melakukan koordinasi dengan pihak mitra, dan melakukan semacam Focus Group Discussion singkat pada Sabtu 14 Juli 2018. Hadir pada kegiatan tersebut kepala sekolah SMP Negeri 6 dan sejumlah guru guna membuat perencanaan bersama. Perencanaan program secara bersama antara tim pengabdi dengan pihak mitra melahirkan kesepakatan tentang siapa melakukan apa terkait dengan pendidikan karakter dan konsep tentang sekolah adiwiyata. Semua dilakukan guna terlaksananya kegiatan PKM dengan baik.

\section{Pihak Mitra}

Sekolah SMP Negeri 6 Sungai Nyalo Mudiak Aie memiliki areal yang cukup luas dengan potensi sebanyak 180 siswa yang terdiri dari 6 Rombongan Belajar (Rombel) masing-masing 2 di kelas 7, 8 dan 9. Potensi dari pihak mitra jelas sangat mendukung kegiatan PKM karena mereka sebagai tenaga yang bisa melaksanakan penanaman, perawatan dan pemeliharaan tanaman yang tumbuh di sekitar sekolah. Meski suasana sekolah mereka cendrung berada di lokasi terpencil, kemauan, semangat dan antusiasme sudah menjadi modal awal untuk melakukan PKM sosialisasi pendidikan karakter menuju sekolah Adiwiyata. Pihak sekolah dengan suka cita menyambut program yang akan dilakukan karena menurut Kepala sekolahnya, keinginan untuk menjadikan SMP 6 sebagai sekolah Adiwiyata sudah ada sejak ia menjabat sebagai Kepala Sekolah sejak satu tahun lalu, tapi masih belum terwujud karena tidak mengetahui secara

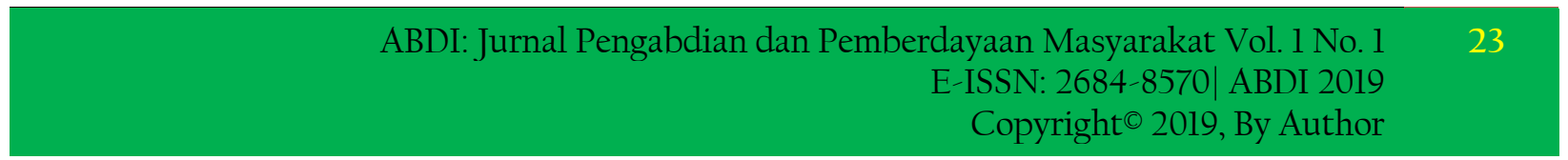


persis juga bagaimana dan apa yang mesti dilakukan di tahap awal, bukan hanya sekadar menanam tanpa tahu tata aturan dan desain jenis tanaman apa yang akan ditanam juga bersedia membawa berapa jenis tanaman utnuk ditanam di skeolah; yakni jenis tanaman obat keluarga (Toga) dan apotik hidup dan tanaman hias berupa bunga-bungaan

\section{Pihak Tim Pengabdian}

Mengetahui situasi sekolah yang memiliki sejumlah kelebihan dan kekurangannya maka tim membantu pihak mitra dengan (1) menyediakan tenaga instruktur atau narasumber dari berbagai disiplin ilmu terkait, termasuk praktisi. Mereka sebagai motivator, penyemangat dan tempat bertanya mengenai pengalaman dalam rangka menuju sekolah adiwiyat. Kemudian (2) menyediakan berbagai jenis tanaman dan tumbuhan serta peralatan untuk menuju lingkungan hidup sehat dan bersih yang digunakan dalam pelatihan sebagai pemancing dan pemicu untuk menuju sekolah adiwiyata. Sejumlah tanaman dan peralatan kebersihan dan taman sekolah yang disediakan oleh tim.

\section{Tahap II}

Kegiatan tahap kedua dilakukan pada Sabtu 11 Agustus 2018. Pada kesempatan ini disepakati tim pengabdian SMP 6 ikut bergabung dengan rombongan tim pengabdian dan penelitian masyarakat di kawasan Mandeh yang terangkum dalam program Nagari Binaan kawasan Mandeh, sungai Nyalo yang diketuai DR. Sitti Fatimah. Dengan rombongan besar ini, masing-masing tim baik tim pengabdian atau penelitian secara bersama-sama berangkat dari Kota Padang menuju Pesisir Selatan tepatnya Nagari Sungai Nyalo kemudian saat tiba di lokasi, setiap tim dengan kendaraan masing-masing yang disewa dari Padang berpencar melaksanakan kegiatan sesuai dengan program pengabdian atau penelitian. PKM Sosialisasi pendidikan karakter pada tahap kedua ini melakukan penyuluhan dan ceramah berupa sosialisasi oleh narasumber yang berkompeten di bidang lingkungan hidup. Tepatnya dari Jurusan Geografi FIS UNP yang membahas tentang sekolah berbasis lingkungan dan upaya penyadaran lingkungan sekolah yang bersih dan sehat. Penyadaran tentang arti bersih lingkungan ini diadakan dalam rangka mengenalkan karakter baik tentang hidup bersih dan lingkungan sehat sehingga diharapkan para siswa mengetahui tentang lingkungan hidup yang sehat dan bersih. Berdasar pengetahuan yang mereka miliki diharapkan untuk bisa menerapkannya di sekolah untuk kemudian dilanjutkan di rumah.

\section{Tahap III}

Kegiatan pada tahap III diadakan pada Sabtu 8 September 2018. Karena lokasi pengabdian yang lumayan jauh dengan medan perjalanan yang cukup ekstrim, kami berharap agat tak terjadi hujan sehingga bisa melaksanakan perjalan dengan lancar yang memakan waktu sekitar 2-3 jam. Mengingat waktu sekolah hanya hingga pukul 12.30 siang dan boat penjemput sudah siap mengantar guru dan siswa ke lokasi masingmasing di Carocok, Pulau Kapo-Kapo dan Mande, maka jadwal yang sudah disepakati bahwa acara hanya hingga pukul 12.301 paling lama, Unyuk itu kami sudah bersiap berangkat pukul 6 pagi dari Padang dengan pertimbangan kegiatan bisa dimulai jam 9 atau setengah sepuluh usai dan tuntas dalam 3 jam berikutnya. Kegiatan pemberian informasi dan berbagi pengalaman dari pihak sekolah yang sudah termasuk dalam sekolah Adiwiyata. Dalam kesempatan ini yang menjadi narasumber adalah Kepala Sekolah SDN 20 Dadok Tunggul Hitam Padang. Seperti Diketahui SD 20 ini merupakan SD yang sudah memenangkan lomba Adiwiyata untuk tingkat Kecamatan, Kota/Kabupaten dan menang di tingkat Provinsi Sumbar. Saat ini sedang dalam proses penilaian untuk lomba sekolah Adiwiyata tingkat Nasional.

\section{Tahap IV}

Kegiatan tahap IV dilakukan pada Sabtu 6 Oktober 2018. Pada kesempatan ini tim menghadirkan narasumber yang berusaha memberikan motivasi para peserta didik dan pendidik untuk mau bergiat dan aktif dalam upaya menjadikan sekolah mereka sebagai sekolah Adiwiyata. Pada tahap ini mereka diberi motivasi, mendapatkan inspirasi dan bersedia melakukan kegiatan penanaman dan meluangkan waktu dalam perawatan tanaman, taman dan tumbuhan yang akan ditanam.

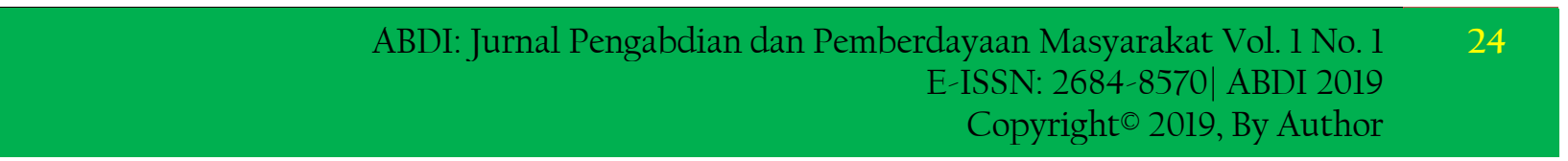


Setelah memberikan motivasi dan inspirasi, para audiens (Siswa dan guru) diminta mempetakan lokasi sekolah mereka dan pada bagian mana yang akan ditanami. Dalam kesempatan tersebut, narasumber yang berasal dari Dinas Lingkungan Hidup Kota Padang Bapak Emrizal SH, beliau jugapemerhati masalah lingkungan dan juga pemilik toko tanaman Hias di Jalan By Pass km19 Padang, serta sudah beberapa kali di undang ke Istana Negara sebagai pendamping kegiatan mendapat penghargaan sekolah Adiwiyata.

Sebagai narasumber yang ahli dan berkompeten di bidangnya, narasumber juga member saran untuk tanaman di gerbang dan pagar diharapkan mereka menanam pohon merambat. Untuk tanaman pelindung harus sekian meter jaraknya dari bangunan. Untuk tanaman jenis obat dan keluarga (TOGA) biasanya di samping bagian belakang ruang sekolah. Demikian pula untuk tanaman hias, ditanam di depan kelas atau digantung di depan kelas.

\section{Tahap V}

Dalam kesempatan ini sekaligus juga dilakukan tahap V yakni melakukan praktek penanaman pohon di sekitar lingkungan sekolah. Praktek penanaman pohon dilakukan segenap para siswa dan para guru dan tim pengabdian sesuai dengan penjelasan yang disampaikan narasumber di ruang kelas. Kegiatan partisipatif ini tampak jelas, (sesuai dengan koordinasi sebelumnya, masing-masing pihak sudah sepakat agar sejumlah pohon dan bunga yang ditanam berasal dari partisipasi pihak mitra dan pihak tim pengabdian.

Tanaman dan tumbuhan yang berasal dari tim pengabdian seperti tanaman jambak Jamaica (3 batang), tanaman lengkeng dan mangga masing-masing satu batang. Kelima jenis tanaman ini merupakan tanaman pelindung yang diharapkan akan melancarkan sirkulasi oksigen dan udara segar di lingkungan sekolah. Tim pengabdian juga menyediakan pot bunga, pot bunga gantung dan tong sampah. Semua pemberian tersebut dijadikan sebagai pemicu atau pemancing agar mereka lebih giat lagi dalam melakukan perawatan dan lingkungan sehat sekolah. Tumbuhan yang berasal dari pihak mitra dalam hal ini siswa sekolah adalah tanaman hias; berbagai jenis tanaman bunga dan juga tanaman obat untuk TOGA atau apotik hidup.

Berdasarkan hasil monitong dan evaluasi, diketahui bahwa telah terjadi perubahan secara fisik dari kondisi sekolah yang semula cenderung gersang dan kering dengan tumbuhan dan pepohonan, kemudian dilakukan kegiatan sosialisasi dan penanaman total 25 batang pohon, tampak hasilnya seperti saat ini; areal komplek sekolah sudah dipenuhi tanaman yang akan terus tumbuh besar dan dipenuhi juga dengan bunga di taman depan kelas, pot, dijumpainya tong sampah dan tanaman bumbu dapur dan TOGA.

Berdasarkan kondisi tersebut di atas dapat dikatakan kegiatan pengabdian yang dilakukan sejak Februari hingga Desember 2018 ini sudah tampak hasil nyata berupa lingkungan sekolah yang sudha mulai mengarah ke lingkungan asri, bersih hijau dan sejuk. Kondisi ini sudah dapat dikatakan sebagai periode awal menuju ke sekolah Adiwiyata. Meski berbagai persyaratan untuk sekolah Adiwiyata masih perlu dibenahi seperti visi dan misi sekolah. KAntin sekolah yang representative (saat ini siswa tidak memiliki kantin sama sekali), dan juga keterlibatan berbagai pihak untuk partisipasi dalam pelaksanaan sekolah Adiwiyata. Satu kendala lainnya, masih bekum bisa dilihat secara jelas target perubahan karakter siswa melalui pendidikan karakter untuk membiasakan hidup dengan lingkungan bersih, sehat dan hijau. Adapun target capaian kegiatan yang sudah diakukan dapt dilihat pada tabel berikut:

\section{Tabel 1. Target Capaian Kegiatan}

\begin{tabular}{|c|c|c|}
\hline No & Hasil kegiatan & Indikator Capaian \\
\hline 1 & $\begin{array}{l}\text { Diperolehnya sikap positif dan keinginan untuk menjadikan } \\
\text { sekolah mereka sebagai sekolah Adiwiyata }\end{array}$ & ada \\
\hline 2 & $\begin{array}{l}\text { Terjadinya perubahan positif di lokasi pengabdian, yakni sekolah } \\
\text { yang dahulunya saat survey awal februari } 2018 \text { masih gersang, } \\
\text { sekarang sudah mulai hijau, ditanami banyak bunga, TOGA. } \\
\text { Disamping itu papan informasi di setiap kelas sudah dipasang }\end{array}$ & ada \\
\hline & $\begin{array}{r}\text { ABDI: Jurnal Pengabdian dan Pemberdayaan Masyaraka } \\
\text { E-ISSN: 2684-8570 } \\
\text { Copyright }{ }^{\circledR} 201\end{array}$ & $\begin{array}{l}\text { Vol. } 1 \text { No. } 1 \\
\text { ABDI } 2019 \\
\text { By Author }\end{array}$ \\
\hline
\end{tabular}


ada sudah dilakukan

\begin{tabular}{lll}
\hline 4 & Melakukan revisi terhadap visi dan misi sekolah yang cenderung & Draf \\
belum terkait dengan sekolah berbudaya dan berwawasan & \\
lingkungan &
\end{tabular}

Sumber: Data observasi lapangan dan wawancara dengan informan

\section{Faktor Pendukung}

Faktor pendukung dalam kegiatan ini adalah ketersedian peralatan dan prasarana yang dibutuhkan untuk kelancaran kegiatan. Kesediaan kepala sekolah untuk dapat menggunakan ruang yang ada di sekolah untuk kegiatan lomba K3 dan menyisihkan sana BOS tahun ini untuk dibelikan ke peningkatan lingkungan sehat dan bersih di kompleks sekolah. Kehadiran seluruh staf pengajar atau guru yang diundang dalam pelaksanaan sosialisasi, sehingga kegiatan sosialisasi dapat berjalan dengan lancar. Kegiatan dapat berjalan lancar juga atas kerjasama tim pengabdian dengan pihak mitra.

\section{Faktor Penghambat}

Faktor penghambat dalam kegiatan ini dapat dikatakan karena lokasi sekolah yang cenderung terpencil dan jauh dari rumah penduduk, Jadi keterlibatan warga tidak terlihat dalam kegiatan penghijauan di skeolah. Iklim yang kadang ekstrim dan tidak kondusif dan yang pasti moda transportasi yang diandalkan hanya boat, meski sudah ada jalan aspal namun cenderung curam, dan tajam sehingga rawan untuk dikendarai, sedangkan ketersediaan transportasi umum jalur darat juga tidak ada. Akses sinyal telekomunikasi tidak ada termasuk juga WIFI Internet tidak ada, sehingga untuk komunikasi dan penggunaan teknologi informasi untuk urusan administrasi sekolah cendrung mengalami hambatan. Lokasi tempat tinggal siswa yang terpisah antar pulau seperti adasiswa yang menetap di Sungai Nyalo, Carocok, Mandeh dan di Pulau Kapo-Kapo. Adakalanya kondisi ini cukup menyulitkan untuk mendatangkan orang tua hadir dalam rapat untuk menyamakan pendapat tentang sekolah Adiwiyata. Kendala lainnya kondisi orang tua yang dominan bekerja sebagai nelayan atau petani yang menyerahkan sepenuhnya urusan sekolah anak mereka ke sekolah dan minim partisipasi untuk program yang ada di sekolah seperti Program Sekolah Adiwiyata ini.

\section{Kesimpulan}

Kegiatan pengabdian masyarakat Sosialisasi pendidikan karakter menuju sekolah Adiwiyata dapat terlaksana dengan baik, sehingga adanya perubahan kondisi sekolah yang gersang menjadi sudah banyak ditanami peohononan. Peningkatan dapat dilihat dari sebelumnya sedikitnya jumlah tanaman di pekartangan sekarang sudah banyak. Aneka jenis bunga, pohon pelindung dan TOGA sudah bisa dilihat di sekolah.

Kegiatan PKM Sosialisasi pendidikan karakter yang menghadirkan tiga orang narasumber yang berkompeten di bidangnya ini diharapkan akan menambah pengetahuan bagi mitra dan melekatnya pemahaman serta memiliki kesadaran bahwa sekolah sehat dan lingkungan bersih sangat penting untuk kegiatan proses belajar mengajar mereka. Selain itu juga menanamkan nilai nilai baik yang menjadi identitas dan karakter siswa di kawasan pesisir ini, meski mereka berada di daerah yang cendrung terpencil, di remote area mereka masih bisa berbuat untuk kebaikan lingkungan sekolah dan berkontribusi di nagari mereka yang mejadi kawasan wisata terpadu mandeh. 


\section{Daftar Pustaka}

Farimah, Siti, dkk. (2017). Desa Binaan Sungai Nyalo Kecamatan XI Tarusan Kabupaten Pesisir Selatan tahun 2017. Laporan Pengabdian Masyarakat, UNP.

Lickona, Thomas. (1991). Educating for Character: How Our School Can Teach Respect and Responsibility. New York: Bantam Books.

Oktama, Rendi Zaki. (2013). Pengaruh Kondisi Sosial Ekonomi terhadap Pendidikan Anak Keluarga Nelayan di Keluarahan Sugih Waras Kecamatan Pemalang Kabupaten Pemalang Tahun 2013. Skripsi, Universitas Negeri Semarang

Sudrajat, Ajat. (2011). Mengapa Pendidikan Karakter? Jurnal Pendidikan Karakter, 1(1).

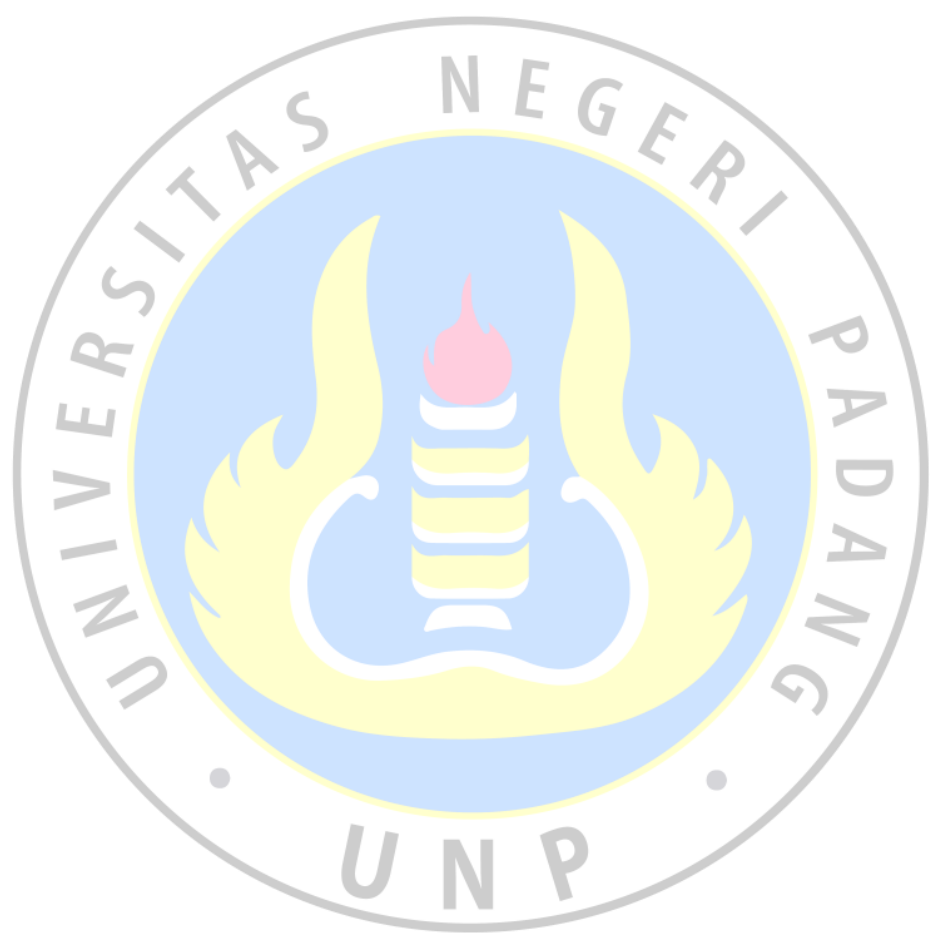

